\title{
History in the Making: Reflections on Timor-Leste in 2012
}

\section{Nicola Trowbridge Cooney}

Princeton University

\section{Introduction}

Sitting under the trees behind the Xanana Reading Room, on a warm August evening in Dili, at the prize-giving ceremony for Kompetisaun Istoria Timor $2010^{1}$, gave special cause to reflect upon the acts of making and narrating history and on the very palpable presence of history in Timor-Leste. This modest but significant event spoke on many levels to the progress made over the past decade, to the agents involved in that process and to a number of critical issues that continue to face the East Timorese people as they move into the next decade of independent rule.

This competition and others like it, such as My Language, My Country (Ha'u nia lian, ha'u nia rai) ${ }^{2}$ aim to encourage the continued establishment of East Timorese national literatures, and the critical preservation of national languages. Such projects are, of course, concrete ways in which culture may be seen as a driving factor in recording and (re)defining national identities. In the case of Istoria Timor, the role of (hi)stories in the consolidation of a national identity was immediately called into question in a rather practical way, as contestants voiced concern and confusion over the definition of the word "istoria", with its multiple meanings in Tetum. Were they supposed to tell a story or a write a history? These people were consciously engaged in the process of creating and writing themselves and their communities into history through their storytelling. 
Beyond the mission of the competition itself, one could not overlook the tangible, visible marks of history on the surroundings. The (hi)story of Timor-Leste was not only being narrated and shaped by her people but was palpably and indelibly inscribed upon the landscape and those who inhabited it. East Timorese often bear the scars, both literal and figurative, of the traumas and memories of a recent and ever-present past. So too the buildings that night had (hi)stories to tell. The Xanana Reading Room, now home to a library and cultural center with a collection of memorabilia from the fight for freedom is a representative microcosm of the East Timorese journey: a Portuguese colonial edifice that once housed Indonesian consular services and reopened in 2000 as Timor-Leste's first post-occupation public library. The partially collapsed structures still manifested signs of damage from a fire in 2006, and yet, like so much else in Dili, they are not merely a testament to incidents past, but to the efforts of the present and the hope for future: they are under construction, showing signs of improvement, and welcoming visitors with open doors.

The audience assembled that night, in the presence of Kirsty Sword Gusmão, ${ }^{3}$ comprised a small sampling of local and foreign guests: community leaders, Timorese writers, families of competition entrants, international researchers, diplomats and NGO workers, reflecting a small snapshot of postcolonial society. Of note were the accessibility of the country's leaders and cultural agents, a visible female presence, a strong sense of community, and the bashful pride of a new generation of writers.

Bearing witness to or participating in history-making at a time and in a place where events worthy of commemorating, "firsts," or even moments significant in that they mark a return to normalcy are frequent, begs the question of what and how we choose to memorialize. As we reflect upon the last decade and look ahead to the future of Timor-Leste, by questioning the symbolism of these milestones, great and small, and being ever mindful of the past, we can better assess the present and begin to project hopes for the future.

2012 was a symbolic year for the Democratic Republic of Timor-Leste, marking the ten-year anniversary since the restoration of independence from Indonesian rule. Taking this moment as its inspiration, our special volume 
began with a deliberately open call for papers addressing any aspects of research in the humanities or social sciences pertaining to contemporary Timor-Leste or its history. We cast a wide net, beyond the usual catchment pool for ellipsis, and were delighted by the enthusiastic response of scholars from across disciplines and across the globe. We must, however, acknowledge that this is not an exhaustive representation of current scholarship on Timor-Leste, and that issues of language and politics will necessarily mean that key players and topics may be missing from our project. Our goal is to bring greater visibility to the East Timorese cultural, social and political landscape and to introduce to a broader audience the exciting and varied scholarship taking place today, and to this end, with the response of our authors, we hope to have succeeded.

The articles gathered here address a number of the issues that were illuminated on that night in 2010, notably those related to history, language, literature, civic inclusion and education. Although they span a diversity of disciplines and approaches they all, in some way or another, reflect upon or engage in a dialogue with that very present past, be it through the lens of literary or gender studies, history or historiography or the social sciences.

The past decade has been one of remarkable progress and reconstruction, with continued consolidation of peace, democracy and development. This stability has, at times, been punctuated by violent outbursts, most notably the army mutiny and coup of 2006 and assassination attempts on the president and prime minister in 2008. These events were forceful reminders of the fragility of peace, but six years on the country held successful presidential and parliamentary elections that ushered in a new term of coalition government, earning Timor-Leste the confidence of the international community, but most importantly, of the Timorese people in their own political system.

In addition to being an anniversary year, 2012 saw a number of significant events in Timor-Leste. On December $31^{\text {st }}, 2012$, UN peacekeeping forces withdrew from the country and handed over full policing duties to the national police force, thereby ending a six-year stabilization mission since the unrest of 2006. Likewise, the Australian-led International Stabilisation Force (ISF) has ceased operations and is scheduled to withdraw from Timor-Leste by April 2013. These signs of progress are certainly worthy of being celebrated, but the 
road ahead is unquestionably one paved with challenges, especially in the arenas of employment, the public sector, education and infrastructure.

The anniversary that inspired this volume was a convenient historical signpost around which to organize our thoughts, focus our attention and coalesce. The commemoration of such dates is a means of not forgetting, or being forgotten, of inscribing events into a national memory, but it is also a politicized act, one that serves to curate, in a sense, the national identity. In the case of Timor-Leste in 2012, the first question we must ask then is what, exactly, we are commemorating?

In this light, what could be a more fitting opening piece to our volume than Douglas Kammen's "Proclaiming East Timor: Historical Reflections on Political Declarations," which provides a thought-provoking challenge to the very notion of the ten-year anniversary of Timor-Leste's independence. If the Constitution states that 2002 marks the restoration of independence won in 1975 , is 2012 merely a convenient year for the international community to celebrate their work in Timor? Bearing in mind the symbolic importance of declarations of independence in the establishment of the nation, Kammen brings to light a series of lesser-known East Timorese political declarations over the course of three centuries, serving both to contextualize and problematize the celebrations of May 20th 2012.

Following on with the question of "celebration," Rui Feijó suggests how Timor-Leste's current political and institutional situation can be seen as a product of controversial choices made at junctures on the road map to independence, which allows for a disambiguation of the several controversies that marked the constitutional and democratic process, thus illustrating the far-reaching effects these have had on the country's political landscape over the past decade. ${ }^{4}$

One cannot, of course, contemplate the future of Timor-Leste's foundation building and political and thus social outlook without taking into consideration the role of women, both in practical terms, such as their inclusion and participation in the democratic process, and more broadly speaking in the collective consciousness of twenty-first century Timorese society. We thus continue with Ann Wigglesworth's "Dreaming of a Different Life: Steps Towards Democracy and Equality in Timor-Leste," which looks in particular at young women 
in rural Timor-Leste, highlighting recent shifts in customary gender roles and exploring women's paths to social and political agency and their access to education. Wigglesworth traces the evolving agency of women in East Timorese society, underscoring their active engagement in struggles for independence, and emphasizing some of the persistent obstacles to their full social and political participation. Whilst the challenges faced by these women are manifold, her research reveals some encouraging signs of improvement and points with cautious optimism to possible solutions moving forward, placing emphasis on the essential role of education along the bumpy path to gender equality.

No discussion of education, inclusion, or of Timorese society in general, may be complete without addressing the often thorny issue of language. Language practices and learning in Timor-Leste have been affected by colonialism, changing language policies, investments in language training, the presence of international organizations and the widespread effects of war and poverty. Multilingualism is prevalent and views on language may be mixed and at times contradictory. Parties actively influencing the linguistic direction of the country are varied and seemingly motivated by a complex set of goals and agendas.

In this context, “Timor-Leste: Multilingual Education for All?” by Kerry Taylor-Leech, analyzes the complex role of multilingualism, language-policies and education in Timor. This article provides essential background to the current linguistic situation and both evaluates and constructively critiques a number of key language policies. Taylor-Leech's research points to convincing evidence as to the potential of mother tongue-based learning to have a positive impact, not only on education, but also on broader social issues.

Carrying on with the topic of language and identity, "Multilingualism and Language Maintenance in the East Timorese Diaspora in Portugal" coauthored by Francesco Goglia and Susana Afonso, shifts our focus to the lessexplored language practices of the East Timorese diaspora in Portugal. Their research reveals some perhaps surprising shifts in attitude towards language and the renegotiation of linguistic identity markers brought about by the immigration experience and context.

The final three works in this volume shift to the literary, with the immigrant experienceand issues oflanguage, identity and memory never far from the surface. 
In a piece that directly references Istoria Timor as a vital initiative for the establishment and publication of fiction writing in Tetum, Isabel Moutinho's "Historicity and Storytelling in East Timorese Fiction in Portuguese," brings to mind again the very questions raised by the writers in that competition. Here, however, Moutinho revisits the Portuguese-speaking diaspora, examining the work of established East Timorese authors writing in Portuguese and highlighting the unique interplay between historicity and storytelling found in their fiction. She identifies and defines what she terms a "uniquely Timorese style of storytelling" through an exploration of the role of historicity in the narratives of Luís Cardoso, Domingos de Sousa and Ponte Pedrinha. Her article provides a panorama of the contemporary East Timorese literary scene and speaks to the coexistence of and strong linkages between tradition, fiction, and history, emphasizing the historical dimensions of storytelling in works that dialogue dynamically with traditional narrative forms and the "Timorese imaginaire".

The work of Luís Cardoso, Timor's most celebrated novelist, is revisited in "Plus ça change: (Post)Colonial Timor-Leste as a Return to (Pre)Colonial Realities in the Novels of Luís Cardoso," by Anthony Soares. This thought-provoking piece examines the way in which Cardoso's oeuvre may be seen to write Timor-Leste into the present through dynamic revisiting of both history and an imagined past. Soares navigates questions of agency and victimhood on a number of levels (authorial, historical, political, cultural) and reads Cardoso's representations of the past, not as marks of victimization, but rather as a cautionary note in a call for East Timorese agency, pointing to the role of the (informed) reader in the understanding of this country's history, past and present.

We conclude with Ana Margarida Ramos' contribution, "Da resistência política à libertação amorosa: eixos temáticos da poesia de Fernando Sylvan," which leaves us with an overview of an emerging polychromatic East Timorese literary landscape. Through insightful close readings, Ramos highlights some key themes explored by Sylvan such as exile, resistance, the Timorese imaginary, memory and love. Her text illuminates a lyric that surpassed the contextual limitations of the sociopolitical realm to affirm itself in the universal, serving as an inspiration to future generations of East Timorese writers. 


\section{Notes}

1 This was the second annual Tetum Story Writing Competition, a literary project founded by John Holdaway and currently sponsored by Timor Aid and the Alola Foundation.

2 A literary project launched in 2010, at the first Conference on National Languages of Timor-Leste.

3 Kirsty Sword Gusmão, Timor's first First Lady is the wife of Xanana Gusmão, Prime Minister and former President of Timor-Leste. She is Goodwill Ambassador for Education, chair of the National Education Committee and founding director of the Alola Foundation.

4 Due to editorial constraints, Rui Feijós article on "Independence, Democracy and Institutional Choices," shall be published in the next ellipsis, volume 11.

Nicola Trowbridge Cooney is a Senior Lecturer in the Department of Spanish and Portuguese Languages and Cultures at Princeton University, where she is Director of the Portuguese language program. She earned her Ph.D. in Romance Languages from Harvard University. Her research interests include Luso-Afro-Asian literatures and cinema, migratory patterns in the Portuguesespeaking world and second language acquisition. 